\title{
ARAŞTIRMA MAKALESİ/RESEARCH ARTICLE \\ THE MAPPILA COMMUNITY AND THEIR CULTURE IN THE SOUTHERN PART OF INDIA, KERALA
}

\author{
Ahammed Ishac CHEMBIRIKA EBRAHIM \\ Dr., SBE, İslam Tarihi ve Sanatları Doktora Programı, Sakarya Üniversitesi, Sakarya, Türkiye \\ PhD Student, Social Science, Department of Islamıc History, Sakarya University, Sakarya, Turkey \\ ishacsahibksd@gmail.com \\ orcid.org/0000-0003-3502-1226 \\ https://ror.org/04ttnw109
}

\begin{abstract}
This study mainly focused on lively society of kerala known as Mappila in southern India. The major parts of Mappila community reside in the Kerala state. Their culture and language of Mappila are known as Malayalam and the people are famous as Malayalis. The original homeland of the Mappilas it included from Cape Comorin to Mangalore part of Karnataka State but here given important for Mappilas living inside the land of kerala. The early history of Mappilas goes through to the Arab people when they landed in the coastal shores of Kerala and rest of history continues from them. Early historian noted that these kerala shore was the main trade of spices and ginger for Arab traders which was the main reason caused for repeated visits of Arabs to Kerala. The cultural point of Kerala Hindu people they opened doors both Islam and Christianity, same time kept religious harmony each other. This paper focusing mainly the significant role of Mappila community, history and development of their culture among kerala society.
\end{abstract}

Keywords: Mappila, Arabs, Islam, Culture, Trade, harmony, Kerala.

\section{HIINDISTTAN'IN GÜNEY KISMI, KERALA'DAKİ MAPPILA TOPLUM VE KÜLTÜRLERI}

\section{Öz}

Bu çalışma esas olarak Güney Hindistan'da Mappila olarak bilinen Canlı Kerala Toplumu üzerine yapılan bir çalışmadır. Mappila Topluluğunun büyük bir kısmı Kerala eyaletinde bulunur. Mappila'nın kültürleri ve dilleri Malayalam olarak bilinir ve Malayalılar olarak tanınırlar. Mappilas'ın ana vatanı, Cape Comorin'den Karnataka eyaletinin Mangalore bölümüne kadar olan kısımdır, ancak burada Kerala'da yaşayan Mappilaslılardan bahsedeceğiz. Mappilas'ın erken tarihi, Kerala'nın kıyılarına indiklerinde Arap halkına kadar uzanır ve tarihin geri kalanı onlardan devam eder. Erken tarihçiler, bu Kerala kıyılarına Arap tüccarlar için ana baharat ve zencefil ticareti yeri olduğunu ve Arapların Kerala'yı tekrar tekrar ziyaret etmesinin ana sebebinin bu olduğunu belirtmektedirler. Kerala Hindu halkının kültürel açıdan hem İslam'a hem de Hristiyanlığa kapılarını açmış, aynı zamanda dini uyumu da korumuştur. Bu makale genel olarak Mappila topluluğunun önemli rolüne, Kerala toplumu arasındaki kültürlerin tarihine ve gelişimine odaklanmaktadır. 
Anahtar Kelimeler:Mappila, Arap, İslam, Kültür, Ticaret, Uyum, Kerala.

Atıf / Cite as: Ahammed Ishac Chembirika Ebrahim. "The Mappila Community And Their Culture In The Southern Part Of India, Kerala” Apjir 5/3 (Aralık 2021), 554-560.

\section{Introduction}

The history of Mappila ${ }^{1}$ which have left some differentiation among Muslims in the three significant regions of kerala southern, central, and northern. We can also found variations within the regions related to urban rural part. The population statistics of northern region of Kerala $69 \%$, central region $15 \%$, and the southern region $16 \%$ of the total population. The percentage of Muslim population of southern regions about $10 \%$, central region $9 \%$, and northern region it is $36 \%$ of the total population. The variation in the ratios it also affect the development of that region. Some of the region of Kerala have strong minority of Muslim population. At same time we can see a distinct cultural profile. $^{2}$

The term "Mappila" related to "broader community consisting of various heterogeneous populations that practice Islam, ${ }^{3}$ Muslim development of southern region related to coastal atmosphere. We know that the Islam its first development started in Indian continent through Arab traders who came to kollam and other parts of Kerala. Muslim culture was remained in the coastal cities but the same time majority of culture was Hindu. ${ }^{4}$ Arab traders ascendant mercantile area in Indian Ocean. Arab geographer noted this Kollam as kaulam which was the trade and coastal area. ${ }^{5}$ In southernmost of kerala main trading ports were the Kozhikode, Muziris, and Kollam which played a significant role as a capital city of Venad. ${ }^{6}$

Kollam was the major port for Chinese ships for exchanging silk goods with traders from the western countries. The famous world traveler like Marco Polo also noted that this Kollam city was the major Commerce City. Chinese exporters continued their relationship with south Indian ports. When throws light on Kollam history it also faced lots of attacks and conflicts. But same time door was opened for Muslim Merchants. ${ }^{7}$

\footnotetext{
${ }^{1}$ M.Naeem Qureshi, “Moplahlar,” Türkiye Diyanet Vakfi İslâm Ansiklopedisi (Ankara ,TDV Yayınları), 2005, 30/ 279280.

${ }^{2}$ Roland E. Miller, Mappila Muslim Culture: How a Historic Muslim Community in India Has Blended Tradition and Modernity (State University of New York Press, 2015), 41.

${ }^{3}$ Manaf Kottakkunnummal, "Indigenous Customs and Colonial Law: Contestations in Religion, Gender, and Family Among Matrilineal Mappila Muslims in Colonial Malabar, Kerala, c. 1910-1928," SAGE Open 4/1 (2014), 2.

${ }^{4}$ A P Ibrahim Kunju, Mappila Muslims of Kerala: Their History and Culture (Trivandrum [Kerala]: Sandhya Publications, 1989), 67.

${ }^{5}$ A. Sreedhara Menon, A Survey of Kerala History (Kottayam: National Book Stall, 1967), 114-122.

${ }^{6}$ Leslie Brown, The Indian Christians of St Thomas: An Account of the Ancient Syrian Church of Malabar (England: Cambridge University Press, 1956), 74-76.

${ }^{7}$ Kunju, Mappila Muslims of Kerala: Their History and Culture, 67.
} 
Tamil and Malayalam culture relatively showing same attachments. Major place was Wakkom which was the origin of some of the revival scholars of Mappila like Abdul Khader Moulavi etc. This modern revival moved step by step to parts of Malabar regions especially Kollam and Alleppey. Miller mention that 'an administrator named Kesava Das brought Rawthar Muslims from Tamil country to Alleppey to offset the Dutch trade control of Cochin, and they played a leading role in the commercial Alleppey culture'. ${ }^{8}$

The Cochin (Kochi) has a major role in central region, which also major place for Muziris. Nowadays it is port of Kodungalur (Cranganore). Same time this place were situated near Periyar River. This kodungalur port was played a major contribution in ancient era. The ancient travelers and geographers mentioned about this port. The Chinese and Roman trader were largely interested this port. Major trading products were Pepper, ginger, turmeric, silk and gems. For Jews and Christians this port became major spot for trading. After this Roman team, Arab traders started to come to southern part of India, mainly they landed coastal region of south India. Same time these Arab traders brought Islam with them and Hindu people were interested on Islam too. ${ }^{9}$

Kodungalur was one of the important center for Chera Kingdom and Perumal rulers whom ruled southern region of India. Periyar rivar region was the major point in all aspects. Before Christians ${ }^{10}$ set up of trading, Muslims were played a major role in Kodungalur and coastal are of Kerala. But after Christiane dominance were increased through pepper export and Portuguese and Dutch took over the trade of Kochi. They also helped Christians more than other communities. Muslim traders whom moved to central region of Kerala. ${ }^{11}$

Muslims of Kodungalur developed social harmony and find new educational methods. After this region became a major center for Mappila intellectual reforms. This modernization education also spread central region of Kerala. The Same time north Malabar region also played a major role on engaging cultural harmony and cultural adaptability. This also shows the Malabar Muslims showed harmony exclusively and inclusively. ${ }^{12}$

Calicut was center of the coastal culture and the commercial trading for entire region. It was one of the oldest port of Kerala. At the time of Zamorin ${ }^{13}$, Calicut port became more

\footnotetext{
${ }^{8}$ Miller, Mappila Muslim Culture: How a Historic Muslim Community in India Has Blended Tradition and Modernity, 42.

${ }^{9}$ T.W Arnold, The Preaching of Islam: A History of the Propagation of the Muslim Faith (London: Constable \& Company, 1913), 199-200.

${ }^{10}$ Kawashima Koji, Missionaries, the Hindu State and British Paramountcy in Travancore and Cochin, 1858-1936 (University of London, 1994), 3-4.

${ }^{11}$ Lincoln Paine, "The Indian Ocean in the Seventh and Eighth Centuries," Maritime Contacts of the Past: Deciphering Connections Amongst Communities, (2014), 46.

${ }^{12}$ Michael Pearson, The Indian Ocean (London,New York: Routledge, 2003), 59-60.

Mahmood Kooria, “An Abode of Islam under a Hindu King: Circuitous Imagination of Kingdoms among Muslims of Sixteenth-Century Malabar," The Journal of Indian Ocean World Studies, (2017), 89. ${ }^{13}$
} 
commercial and through this trade open gate for Arabian traders and for Islam. Step by step commercial ships were carried among Calicut and Hadramaut on southern Arabian coast continuously. Even today also at Beypore near Calicut, a few wooden dhows are still being made by hand in the old manner. Arabs and Calicut Mappilas each other continue to take pride in their Arab descent and connection. ${ }^{14}$ Through this connection Mappila economic stability were strong, that's why Mappila community's space were strong among other communities. ${ }^{15}$ So that Calicut remained major place for Hindu - Muslim harmony and cooperation. ${ }^{16}$ Mercantile cooperation and relationship was the major reason for the spread of Islam at Malabar Coast. By the reason of trade, commerce and Islamic faith people from different parts of country settled in Malabar coastal area. Untouchable group of people accepted Islamic faith because of hierarchy among their society and attracted Mappila Community life style and behaviour. ${ }^{17}$

As per historical evidence, conversation to Islam happened in different context. The continue trading and relationships of Arab traders caused intermarriage and lots of Nayar family and lower caste people attracted Mappila customs which was similar to their way of life. At this time there was context of kingdoms power, trade and conversion. ${ }^{18}$

Kannur also played a major role for development of Mappila Culture. The growth of Islam was by intermarriage and conversation of Nayars and other classes of Hindu society. Lots of Nayar members were accepted Islam and Nayars opened door for Muslim traders too. After Ali Raja conversion ${ }^{19}$ to Islam Mappila kingdom established. Ali raja contributed more helps and supports for Muslim traders and this time female Muslim rulers (Beevis) also helped Arabs and Mappila community. This royal family played important contribution for the development of Muslim community. ${ }^{20}$

The lower castes of Hindu and outcastes they attracted the views of Islam and accepted Islam. ${ }^{21}$ After adaptation of Islam, this group of people empowered socially and

\footnotetext{
${ }^{14}$ K.V. Krishna Ayyar, The Zamorins of Calicut (From the Earlist Times down to A . D. 1806) (Calicut: The Norman Printing Bureau, 1938), 36-50.

${ }^{15}$ Muhammadali P Kasim, "Mappila Muslim Masculinities: A History of Contemporary Abjectification," Sage 23/ (2020), 545 .

${ }^{16}$ Edward Simpson, Muslim Society and the Western Indian Ocean: The Seafarers of Kachchh, ed. Zulfikar Hijri Ruth Barner, Journal of the Economic and Social History of the Orient (London,New York: Routledge Indian Ocean Series, 2008), 51/50.

${ }^{17}$ Kasim, "Mappila Muslim Masculinities : A History of Contemporary Abjectification," 545.

${ }^{18}$ Kottakkunnummal, "Indigenous Customs and Colonial Law: Contestations in Religion, Gender, and Family Among Matrilineal Mappila Muslims in Colonial Malabar, Kerala, c. 1910-1928," 2-3.

${ }^{19}$ Peter Hardy et al., "Kolathunadu, 1663-1723," (2005), 1-8.

${ }^{20}$ Stephen F. Dale, "Trade, Conversion and the Growth of the Islamic Community of Kerala, South India," Studia Islamica, Brill, (1990), 156-164.

${ }^{21}$ Arnold, The Preaching of Islam: A History of the Propagation of the Muslim Faith, 204.
} 
economically. The kingdom of Hyder Ali and and Tipu Sultan ${ }^{22}$ strengthened relationship with Arabs and Mappila community got more base under this kingdom. After conversion transformed into Islamic character. ${ }^{23}$ The Islamic basic education done from Maunat-ulIslam Sabha at Ponnani. ${ }^{24}$ Even nowadays also this formal educational center continue duties which established. The newcomers of Islam they learned Islamic basic education, culture and tradition. By the help of this center, many people came out to learn about Islam and Muslim. After conversion to Islam, they also became the part of Mappila community. ${ }^{25}$

Malabar coastal area linked with fisher- folk of Mappila Muslim. From Mangalore in the north to Cochin in the south these fisher group accepted Islam and followed Islamic faith. Fisher groups were very innocent people and followed their own lifestyle and same time worked hard for commercial trading and export. They helped Arab traders each other. ${ }^{26}$

Decline of Mappila community in trading and from political power were started at the time of Portuguese. Mappila muslim community became landless, unemployed and fishermen. Moreover, 'changing geopolitical conditions compelled the Zamorins to shift their allegiance to the Portuguese leaving the Mappilas in a miserable condition'. ${ }^{27}$

\section{Conclusion}

This paper mainly focused about Mappila Muslims in Kerala and their way of conversion to Islam and life. Article throws light on Mappilas and Hindus harmony which helped to accept Islam other low caste people. Basically Mappila Muslims included Fisher community too. Kozhikode and Kannur was major centre for Mappila Muslims. Arabs were married and increased trade relationship with Kerala through Mappila Muslims. Through this marriage increased interreligious relations and opened door to customary adaptation. Arab traders also started to learn Malayalam language by the help of Mappila

\footnotetext{
${ }^{22}$ David Hardiman - David Ludden, The New Cambridge History of India. Volume 4, Part 4, An Agrarian History of South Asia, The American Historical Review, 2000, 105/139. Rajeshwari Datta, "The India Office Library: Its History, Resources, and Functions," The University of Chicago 36/2 (1966), 99-148.

${ }^{23}$ Dietmar Rothermund, "Mysore," Encyclopedia of India, ed. Stanley Wolpert (Thomson Gale, 1950), 3 K-R/207. Bipin Shah, "Barbosa Duarte Journey to Malabar Coast Part-2 Covering Maharashtra," State University of New York, (2016), 1-49. Renu Elizabeth Abraham, History Writing and Global Encounters in Sixteenth-Century Kerala (University of Kent, 2020), 68.

${ }^{24}$ R.E Miller, "Mappila," The Encyclopaedia of Islam (Leiden: Bril, 1991), V1/458-466. Qureshi, "Moplahlar," 30/ 279-80. Kooria, "An Abode of Islam under a Hindu King: Circuitous Imagination of Kingdoms among Muslims of Sixteenth-Century Malabar," 89-91. Shafeeq Hussain Vazhathodi Al-hudawi - Development Directorate, "The İslamıc Educational Tradition in Kerala: How It Practiced the Concept of Knowledge In İslam" December 2013 (2014), 1-5.

${ }^{25}$ Arnold, The Preaching of Islam: A History of the Propagation of the Muslim Faith, 203.

${ }^{26}$ Dorian Q. Fuller et al., "Across the Indian Ocean: The Prehistoric Movement of Plants and Animals," Antiquity 85/328 (2011), 547. Zayn al-Dīn ibn 'Abd al-'Azīz Malībārī, Tohfut-Ul-Mujahideen: An Historical Work in the Arabic Language, Trc. Lieut M. J. Rowlandson (London: Oriental Translation Fund of Great Britain and Ireland, 1833), 63-64.

${ }^{27}$ Kasim, "Mappila Muslim Masculinities : A History of Contemporary Abjectification," 545.
} 
Muslims. The women who married Arabs, by the mother children's were adapted Malayalam customs. Mappila Muslim they adopted Islamic character and Malayali way of life too. So this cultural exchange helped to happened various events. 


\section{Reference}

Abraham, Renu Elizabeth. History Writing and Global Encounters in Sixteenth-Century Kerala. University of Kent, 2020.

Al-hudawi, Shafeeq Hussain Vazhathodi - Directorate, Development. "The İslamıc Educational Tradition in Kerala : How It Practiced the Concept of Knowledge In İslam” December 2013 (2014), 13.

Arnold, T.W. The Preaching of Islam: A History of the Propagation of the Muslim Faith. London: Constable \& Company, 2nd Ed., 1913. https://www.muslim-library.com/dl/books/english_The_Preaching_Of_Islam.pdf

Ayyar, K.V. Krishna. The Zamorins of Calicut (From the Earlist Times down to A . D. 1806). Calicut: The Norman Printing Bureau, 1938.

Brown, Leslie. The Indian Christians of St Thomas: An Account of the Ancient Syrian Church of Malabar. England: Cambridge University Press, 1956.

Dale, Stephen F. "Trade, Conversion and the Growth of the Islamic Community of Kerala, South India." Studia Islamica, Brill, 155-175.

Datta, Rajeshwari. “The India Office Library: Its History, Resources, and Functions.” The University of Chicago 36/2 (1966), 99-148.

Fuller, Dorian Q. et al. "Across the Indian Ocean: The Prehistoric Movement of Plants and Animals." Antiquity 85/328 (2011), 544-558. https://doi.org/10.1017/S0003598X00067934

Hardiman, David - Ludden, David. The New Cambridge History of India. Volume 4, Part 4, An Agrarian History of South Asia. The American Historical Review, 2000. https://doi.org/10.2307/2652068

Hardy, Peter et al. "Kolathunadu, 1663-1723," 1-8.

Kasim, Muhammadali P. "Mappila Muslim Masculinities: A History of Contemporary Abjectification.” Sage 23/ (2020), 542-557. https://doi.org/10.1177/1097184X18803658

Koji, Kawashima. Missionaries, the Hindu State and British Paramountcy in Travancore and Cochin, 1858-1936. University of London, 1994.

Kooria, Mahmood. “An Abode of Islam under a Hindu King: Circuitous Imagination of Kingdoms among Muslims of Sixteenth-Century Malabar." The Journal of Indian Ocean World Studies. https://doi.org/10.26443/jiows.v1i1.21

Kottakkunnummal, Manaf. "Indigenous Customs and Colonial Law: Contestations in Religion, Gender, and Family Among Matrilineal Mappila Muslims in Colonial Malabar, Kerala, c. 1910-1928." SAGE Open 4/1 (2014), 215824401452541. https://doi.org/10.1177/2158244014525416

Kunju, A P Ibrahim. Mappila Muslims of Kerala: Their History and Culture. Trivandrum [Kerala]: Sandhya Publications, 1989. https://doi.org/Chronic ischaemic mitral regurgitation. Current treatment results and new mechanism-based surgical approaches ${ }^{2}$

Malībārī, Zayn al-Dīn ibn 'Abd al-'Azīz. Tohfut-Ul-Mujahideen: An Historical Work in the Arabic Language, Trc. Lieut M. J. Rowlandson. London: Oriental Translation Fund of Great Britain and Ireland, 1833.

Menon, A. Sreedhara. A Survey of Kerala History. Kottayam: National Book Stall, 1967.

Miller, R.E. "Mappila." The Encyclopaedia of Islam (NEW). V1/31-79. Leiden: Bril, 1991. http://books.google.com/books?id=apU3AAAAIAAJ

Miller, Roland E. Mappila Muslim Culture: How a Historic Muslim Community in India Has Blended Tradition and Modernity. State University of New York Press, 2015.

Paine, Lincoln. "The Indian Ocean in the Seventh and Eighth Centuries." Maritime Contacts of the Past: Deciphering Connections Amongst Communities, 37-53. https://doi.org/10.1017/CB09781107415324.004

Pearson, Michael. The Indian Ocean. London,New York: Routledge, 2003. https://doi.org/10.1007/s10308-0060083-1

Qureshi, M.Naeem. “Moplahlar.” Türkiye Diyanet Vakfi İslâm Ansiklopedisi (Ankara ,TDV Yayınlarl). 279-280, 2005.

Rothermund, Dietmar. “Mysore.” Encyclopedia of India. ed. Stanley Wolpert. 3 K-R/440. Thomson Gale, 1950.

Shah, Bipin. "Barbosa Duarte Journey to Malabar Coast Part-2 Covering Maharashtra." State University of New York.

Simpson, Edward. Muslim Society and the Western Indian Ocean: The Seafarers of Kachchh. ed. Zulfikar Hijri Ruth Barner. Journal of the Economic and Social History of the Orient. London,New York: Routledge Indian Ocean Series, 2008. https://doi.org/10.1163/156852008x317833 